\title{
ERP System Implementation and Business Process Change: Case Study of a Pharmaceutical Company
}

\author{
Vesna Bosilj Vuksic and Mario Spremic \\ Department of Business Computing, Graduate School of Economics \& Business, University of Zagreb, Croatia
}

\begin{abstract}
The main objective of this paper is to present the impacts of information technology (IT) and enterprise resource planning (ERP) systems in business process renovation and to discuss selected aspects of the business processes and information modelling. This study presents the results of research conducted on reengineering business processes in Croatian companies, together with the results of analysis of the status and characteristics of ERP systems in Croatian companies. The results of this study were used to form hypotheses, which were then analyzed and compared against the results of a case study conducted by the authors on business process reengineering and the implementation of the SAP software solution in PLIVA pharmaceutical industry, Incorporated (PLIVA pharmaceuticals, Inc).
\end{abstract}

Keywords: business process change, enterprise resource planning (ERP), business process modelling, SAP, PLIVA pharmaceuticals Inc.

\section{Introduction}

In order to survive in highly competitive business environments, companies have to continuously change their business processes. New conditions in the marketplace have provided a special stimulus to modelling business processes over the past ten years: product expansion, competitive sales conditions, development of global distribution networks, better informed customers, and the orientation of businesses towards satisfying individual needs of the customer. In the light of this, business process reengineering has often been employed, and information technology is a frequently utilized approach used to improve business processes.

This paper stresses the necessity for organizational restructuring in the context of global in- formation connectivity. Business Process Reengineering (BPR) is an organizational method demanding radical redesign of business processes in order to achieve greater efficiency, better quality and more competitive production (Hammer and Champy, 1993). It means analyzing and altering the business processes of the organization as a whole.

A business process includes activities and tasks that cross functional and/or organizational boundaries. Information technology (IT) is the most important factor in enabling newly redesigned processes. Modern information technology is oriented towards business processes and communications between persons using these processes, and is therefore called process and information technology (Ould, 1995). In that way, BPR can be described as organizational process redesign, with the direct influence of IT. Despite the fact that many academics and practitioners agree with this idea, BPR and information systems modelling are still performed separately. The objective of this paper is to examine this domain and to propose a framework for business process modelling and IT integration.

The primary objective of this paper was to explore the relationship between IT, ERP and business process change. The evaluation of BPR is described in Section 2. A brief overview of ERP systems and the results of ERP systems' analysis conducted in Croatia are presented (Section 3 ). The framework for business process renovation and ERP systems modelling is provided in Section 4, as are the results of research on BPR 
conducted in Croatian companies. A case study of ERP system solutions implemented in the pharmaceutical company PLIVA is described in Section 5. Finally, the conclusions outlining the main findings of this research are presented in Section 6.

\section{Reengineering Business: History and Evolution}

BPR has become one of the most popular topics in organizational management, creating new ways of doing business (Tumay, 1995). Many leading organizations have conducted BPR in order to improve productivity and to gain a competitive advantage. However, regardless of the number of companies involved in reengineering, the success rate of reengineering projects is less than 50\% (Hammer and Champy, 1993). Some frequently mentioned problems related to BPR include the inability to accurately predict the outcome of radical change, difficulty in capturing existing processes in a structured way, lack of creativity in process redesign, the level of costs incurred in implementing the new process, and the inability to recognize the dynamic nature of the processes.

On the other hand, CPI (Continuous Process Improvement) integrates methods such as industrial engineering, systems analysis and design, socio-technical design and total quality management (Davenport, 1993; Galliers, 1998). Continuous improvement refers to programs and initiatives that emphasize incremental improvements in work processes and outputs over an open-ended period of time (Davenport and Beers, 1995). Several researchers suggest that the use of CPI techniques dramatically increases competitive advantage. Furthermore, it is particularly suggested that TQM (Total Quality Management) should be integrated with BPR (Al-Mashari and Zairi, 1999).

Business Renovation (BR) integrates the radical strategic method of BPR and more progressive methods of Continuous Process Improvement (CPI) with adequate IT (Kovacic et al., 2001). Process renovation is a reengineering strategy that critically examines current business practices and procedures, re-thinks them through and then redesigns the mission-critical products, processes and services (Prassad, 1999).
The analysis of published BPR cases suggests that Hammer's well-known definition of BPR is too limited, as it focuses on processes and ignores other important aspects of institutions such as organizational structure, people, communication and IT (Grant, 2002).

In the 1990s, BPR focused on internal benefits such as cost reduction, company downsizing and operational efficiency, which are more tactically than strategically focused. Nowadays, e-business renovation strategies focus on the processes between business partners and the applications supporting these processes. These strategies are designed to address different types of processes with the emphasis on different aspects (Phipps, 2000; Kalakota and Robinson, 2001): customer relationship management, supply chain management, selling-chain management, and enterprise resource planning.

By strictly pursuing a process perspective, businesses are restructured across functional and hierarchical boundaries. To accommodate these changes, organizations may need to be restructured around these new business processes (Grover and Malortha, 1997). BPR driven by ebusiness should not be based solely on the radical redesign of intra-organizational processes, but should be extended to the entire business network (internal and external). An enhancement geared to include inter-organizational processes is called Business Network Redesign (Alt et al., 2000). Business Network Redesign (BNR) is driven by global information connectivity and e-commerce. It identifies interorganizational processes to redesign and extend the strengths of BPR to networking among business partners. An online partnership must extend far beyond presenting promotional and pre-sales activities on company Web sites. It has to drill deep into company processes in order to create totally different business models. Therefore, most companies need to reevaluate and Web-enable core processes in order to strengthen customer service operations, streamline supply chains and reach new customers. Traditional companies are forced to change their current business models and create new ones.

It must be stressed that IT applications have the strongest impact on the standardization or elimination of process variations. For that reason, BPR and IT infrastructure strategies, both of 
which are derived from organizational strategy, are in need of effective alignment to ensure the success of the BPR initiative (Al-Mashari and Zairi, 1999). The merger of the two concepts has resulted in the latest concept: business engineering $(\mathrm{BE})$. The entirety of $\mathrm{BE}$ lies in radical, process-oriented solutions that have been greatly enhanced by IT.

\section{ERP Overview}

Enterprise Resource Planning systems automate and integrate the core functionality of an organization. ERP facilitates the flow of information among the different functions of an enterprise, while also permitting information sharing across organizational units and geographical locations (Markus et al., 2000).

\subsection{A Brief History of ERP}

According to Kalakota and Robinson (2001) the evolution of ERP systems can be divided into 4 phases: Manufacturing Integration, Enterprise Integration, Customer-centric Integration and Inter-enterprise Integration.

\section{Phase 1: Manufacturing Integration (MRP)}

In the 1970s, production-oriented information systems were known as manufacturing resource planning (MRP) systems. The aim of the MRP was to schedule and release manufacturing work orders and purchase orders. In the 1980s, the extended version of MRP, called MRP II, was developed to focus on other business functions, including order processing, manufacturing and distribution. Since its data and processes were not integrated with those in the rest of the enterprise, MRP II was improved and renamed ERP.

\section{Phase 2: Enterprise Integration (ERP)}

In the mid-1990s, ERP became the latest enhancement of MRP II, with added "back-office" functions such as finance, warehousing, distribution, quality control and human resource management, integrated to handle the global business needs of a networked enterprise (Siriginidi, 2000). The main goal of the ERP was to facilitate information sharing and integration across these varying functions and to provide automated solutions to a wide range of business processes. The goal of integration was to use technology to develop process standardization across multiple business units in order to improve efficiency and generate greater return on capital (Kalakota and Robinson, 2001).

\section{Phase 3: Customer-centric Resource Planning (CRP)}

The range of ERP functions was further expanded at the end of the 1990s to include "frontoffice" functions such as sales, marketing and e-commerce. E-commerce applications needed to be connected to back-end systems and thus forced many ERP software providers (including SAP, PeopleSoft and BAAN) to reinvent themselves as CRP providers. While traditional ERP solutions were equipped to support the "maketo-stock/configure-to-order business model", CRP systems are able to meet the e-commerce "build-to-order/fulfil-to-order" requirement. Effective manufacturing and service delivery in the e-commerce model require customer-centric, continuous planning instead of the classic ERP assumption of long planning cycles.

\section{Phase 4: Inter-enterprise Integration (XRP)}

Since the world of the 2000s has become one of interconnected enterprises creating global information systems, the scope of ERP systems comprises the entire value chain of the enterprise, its customers, suppliers and trading partners. The main goal of the XRP system is to provide intelligent decision-support capabilities in order to reduce inventory, foster strategic pricing, improve cycle times and increase customer satisfaction throughout the supply chain management and selling chain management. To achieve this goal, an XRP model must support the integration of external and internal business activities with the supplier's and customer's information and processes. 


\subsection{ERP Software Industry Trends}

Competition in the ERP software industry is very strong, with over 500 software producers fighting for their market share. Producers can be divided into two groups: (1) companies that offer an integrated suite of applications and (2) those that make innovative niche products and solutions for supply change management, customer relationship management, advanced demand planning software (APS) and e-business applications. The major players in the first group are SAP AG, Oracle, PeopleSoft and J.D. Edwards, while the second group consists of several leaders like Siebel Systems and Ariba. Table 1 provides a breakdown by company of license revenue, market share and estimated growth. By 2001, SAP reported that it alone accounted for more than 36,000 software installations in 15,000 companies across 120 countries (SAP, 2001).

\begin{tabular}{|l|c|c|c|}
\hline $\begin{array}{c}\text { Company } \\
(2000 \text { data })\end{array}$ & $\begin{array}{c}\text { Sales } \\
\text { (in \$ millions) }\end{array}$ & $\begin{array}{c}\text { Market } \\
\text { Share }\end{array}$ & $\begin{array}{c}\text { Estimated } \\
\text { Growth }\end{array}$ \\
\hline \hline SAP AG & 5,939 & $30 \%$ & $10 \%$ \\
\hline Oracle & 2,870 & $15 \%$ & $14 \%$ \\
\hline PeopleSoft & 1,736 & $9 \%$ & $17 \%$ \\
\hline J.D. Edwards & 980 & $5 \%$ & $2 \%$ \\
\hline Geac & 901 & $5 \%$ & $0 \%$ \\
\hline Others & 7,228 & $36 \%$ & $8 \%$ \\
\hline
\end{tabular}

Table 1. Profile of leading ERP companies (Source: AMR, 2001).

While businesses such as Cisco Systems, Eastman Kodak, and Tektronix have gained the expected benefits of ERP systems, many companies like Hershey (Stedman, 1999), Nike (Konicki, 2001) and Whirlpool (Collet, 1999) have experienced difficulties. For example, FoxMeyer Drug, a $\$ 5$ billion pharmaceutical wholesaler, recently filed for bankruptcy. FoxMeyer argued that major problems were generated by a failed ERP system, which created excess shipments resulting from incorrect orders (Kalakota and Robinson, 2001). Dell Computer spent tens of millions of dollars on an ERP system that was too monolithic and too rigid for their changing global operations.

A study conducted by the Boston Consulting Group showed that only one out of three ERP applications could be classified as successful (Soh et al., 2000). A recent study indicates that the ERP failure rate may be even greater than 50 percent: 40 percent of all ERP installations achieve only partial implementation and 20 percent of attempted ERP adoptions are scrapped as total failures (Trunick, 1999, Escalle et al., 1999). Ptak and Schragenheim (1999) also report that between 60 and 90 percent of ERP implementations do not achieve the return on investment identified in the project approval phase.

Despite the problems identified in ERP applications, the number of companies opting for ERP systems will grow continuously, heading in 3 directions: (1) the ERP vendors will integrate their solutions supporting e-business and workflow-management; (2) the ERP applications will be upgraded to target additional functional niches (CRM, SCM, APS); and (3) the ERP solutions will be simplified to target hundreds and thousands of midsize and small companies.

\subsection{The Analysis of ERP Systems in Croatia}

With the assistance of the Ministry for Science and Technology, a new program entitled "Comparative analysis of program support information systems in Croatia" was launched in November 2000 (Fertalj et al., 2002). The objective of this research was to offer users of ERP systems information on the status of the market and the possible expenses associated with obtaining, implementing, developing and maintaining an ERP system. System suppliers and companies which deal with the implementation of ERP systems have attempted to provide information on the desirable characteristics of these systems from the perspective of the user.

For the purpose of analysis, the expanded of ERP software, by the company IDC (International Data Corporation), is program support for a minimum of 3 of the 4 segments of operation (IDC, 2000):

- accounting

- manufacturing

- material management/distribution

- human resource management, payroll 
Keeping the variety of modules of commercial ERP packages in mind, the authors have defined the desired characteristics for the following components:

- finance/accounting

- quality control

- supply

- general characteristics

- sales

- product management

- inventory management

- production calculations

- product calculations

Fourteen companies which deal with complete ERP solutions were called to participate in the study, as were 10 companies which are users of ERP solutions (whether those be complete packages or systems the company itself had developed). Of those invited, $38 \%$ participated in the initial phases of the research, while only $25 \%$ of companies participated in the evaluation of their solutions, among them PLIVA. PLIVA's integral information system is described in detail in Section 5. In this study, 3 domestic program solutions were analyzed, with the BAAN and SAP solutions analyzed as foreign products.

Individual components were evaluated, such that each component was granted a range of possible scores, and for each component the importance of the expressed weighted factor of that component was assessed. The results of this evaluation showed that the best supported components were accounting and sales (about $60 \%$ ), followed by Supply and inventory management (about 50\%), while the poorest represented program support were in the components production management and quality control.

Based on this research, it was concluded that the solutions offered by domestic companies are frequently incomplete and inadequate, while the primary characteristics of obtaining foreign ERP packages in Croatia are:

- large initial investment,

- need for substantial adaptations both in the organization and in program support,

- time period for implementation of the complete solution is too long (3-4 years),
- large consulting expenses,

- occasional inadequacy of the consultant and instability of the supplier.

It is assessed that the greatest advantages of the implementation of ERP systems in Croatian firms include: the integration of information on financial operations, the standardization of business processes and the standardization of information on human resources.

The results of this research were compared to results of a case study conducted in the company PLIVA. The similarities and differences were defined, which might assist potential users of ERP systems in Croatia in their decision making.

\section{Framework for BPR and ERP Integration}

Recent BR research papers demonstrate the critical role of information technology in business process restructuring (Grant, 2002; Arora and Kumar, 2000). Previously, IT was used to help companies automate business processes, but recently, technology is being used to change those processes radically. IT plays the key role as an enabler in business process renovation and there is a strong correlation between the quality of information systems within an organization, the improvement of an overall corporate culture and the organization's strategies (Lederer and Sethi, 1996).

Several authors have claimed that Hammer's well-known definition is too limited as it suggests BPR is about making changes to processes, while IT plays only an enabling role (Grant, 2002; Koch, 2001; Siriginidi, 2000). The contributions of IT in BPR could be categorized in two different ways (Chang, 2000). Firstly, IT contributes heavily as facilitator to the process of reengineering. Secondly, IT contributes in the reengineering process as an enabler to master the new process in the most effective way (Davenport and Short, 1990). The advantages and disadvantages of IS modelling and the ERP system as a tool for realizing business renovation is discussed further. This discussion is corroborated by the study results on reengineering projects conducted in Croatian companies, which clearly point out the fundamental reasons, objectives and problems associated with the implementation of BRP projects. 


\subsection{The Role of ERP in Reengineering Business Practices}

In the past, companies used to decide how they wanted to do business and then made a decision about a software package that best supported their business processes. This was changed with ERP systems that required the business processes to be modified to fit the system (Davenport, 1998). Recent ERP solutions are modular and flexible, and thus can be customized to a certain degree. There are, however, constraints in design possibilities, while major modifications are complex and extremely costly. The implementation delays and ERP product modifications could result in exponential growth in both direct and indirect costs. From the above analysis, it would always be better to complete the BPR project prior to information system modelling and ERP system development. Since the implementation of large information systems is not possible without first altering business processes, reengineering is essential in order to extract maximum benefit out of the ERP products.

However, analysis of business practices shows a different approach. Initiating BPR projects prior to ERP means that the companies must provide resources for two successive projects. The reason why many companies chose to conduct ERP system development was to attempt to solve all their organizational problems without reengineering business processes first. In addition to procedures and rules, ERP implementation significantly impacts company culture, organizational structure, business processes.

Furthermore, ERP applications integrate many of the best business practices and much knowledge that could be worthwhile if included as a part of BPR projects. By taking the best practices inherent in ERP applications, companies can change their processes simultaneously with technological change. As a result, many companies changed their business processes to fit the ERP system requirements, and the possibilities of ERP systems have been used to underpin BPR (Kooch, 2001, Chen, 2001). As ERP systems have traditionally taken too long to implement, a dynamic and incremental implementation of ERP components is recommended as opposed to massive reengineering.

It must be stressed that failing to match business processes with a company's ERP system can derail even the best-run firms. Managers and employees must be able to assess the technological and business process issues involved with specific ERP applications. It is well known that overcoming employee resistance can be a critical factor for the successful completion of the project and the top management must provide leadership for all changes, efforts, objections and disagreements that arise in the process of reengineering and ERP implementation. The many enterprises assessed indicate that several approaches to the combination of BPR and ERP are involved and that they lead to different levels of integration.

The synergy created and manifested by ERP and BPR, along with new employee energy, can provide organizations with unprecedented capabilities they have never envisioned prior to ERP implementations (Chenn, 2001). Ahmed (1999) also points out that evidence of practical experiences of success of business process change-related programs require ongoing effort for at least three to five years, even reaching time frames of around 10-20 years for the realization of full potential. Consequently, the focus of ERP implementations has shifted from matching business processes with the ERP system to developing "knowledge-workers" that can quickly understand and work with redesigned processes and realize the ERP-enabled benefits.

\subsection{BPR Projects Research in Croatian Companies}

The key objective of this research was to examine a number of issues regarding BPR practices on a sample of the '400 Largest' Croatian companies, ranked according to 2001 annual revenues. To address the study objectives, a survey questionnaire was considered the most appropriate research methodology. The study was conducted by IT researchers from the Department of Information Science and Business Computing of the Faculty of Economics and Business in Zagreb (Croatia) in 2002. The questionnaire consisted of four sections:

- general information about the company,

- structure and current state of IS, as well as SISP practices,

- business process innovation issues, and 
- e-business practices.

\section{Research Methodology and Sample}

This paper in particular focuses on the third section of the questionnaire.

It should be stressed that a similar survey was conducted in 2000 (Bosilj-Vuksic et al., 2001). The 2000 survey was performed on the same sample ('400 Largest' Croatian companies according to 1999 annual revenues) and with exactly the same questionnaire, which formed a solid basis for discussion and analysis of trends, presented in Tables 2 and 3.

The questionnaire was pre-tested on postgraduate and doctoral students for content validity, comprehensiveness and readability. Once feedback from the pre-testing had been obtained, the questionnaire was pilot tested with five senior IS executives. The 2002 survey was performed from March 2002 to April 2002 and was conducted by a professional market research agency through verbal communication with IS execu-

\begin{tabular}{|l|c|c|c|c|}
\hline \multirow{2}{*}{ BPR PROJECTS } & \multicolumn{2}{|c|}{2000} & \multicolumn{2}{c|}{2002} \\
\cline { 2 - 5 } & $\begin{array}{c}\text { Number of } \\
\text { companies }\end{array}$ & Percent & $\begin{array}{c}\text { Number of } \\
\text { companies }\end{array}$ & Percent \\
\hline \hline Completed & 6 & $10 \%$ & 4 & $6.4 \%$ \\
\hline Conducting & 12 & $19 \%$ & 14 & $22.6 \%$ \\
\hline To be conducted in 6 months & 3 & $5 \%$ & 7 & $11.3 \%$ \\
\hline To be conducted in 2 years & 17 & $27 \%$ & 20 & $32.3 \%$ \\
\hline To be conducted in 5 years & 6 & $10 \%$ & 6 & $9.7 \%$ \\
\hline Not planned & 18 & $29 \%$ & 11 & $17.7 \%$ \\
\hline
\end{tabular}

Table 2. BPR projects status in surveyed Croatian companies.

\begin{tabular}{|l|c|c|}
\hline BPR PROBLEMS & $\begin{array}{c}\text { 2000 Survey } \\
\text { Mean }\end{array}$ & $\begin{array}{c}\text { 2002 Survey } \\
\text { Mean }\end{array}$ \\
\hline \hline Problems in recognizing “key" processes & 3.13 & 3.41 \\
\hline Not prepared for changes & 3.4 & 3.38 \\
\hline Lack of business function interactivity and interoperability & 3.33 & 3.19 \\
\hline Barriers to massive organizational changes & 3.25 & 3.15 \\
\hline Lack of IT and knowledge & 2.93 & 3.09 \\
\hline Lack of motivation or education & 3.31 & 3.01 \\
\hline Lack of employee support & 3.29 & 3.00 \\
\hline Lack of vision or strategic plan & 3.25 & 2.95 \\
\hline "Traditional” organizational structure & 2.93 & 2.86 \\
\hline Problems in cooperation between middle-level management & 2.63 & 2.86 \\
\hline Lack of resources (human, financial) & 3.13 & 2.8 \\
\hline No BPR project leader & 3.07 & 2.7 \\
\hline Poor communication between project team members and other employees & 3.13 & 2.6 \\
\hline Lack of coordination between corporate business plan and IT development & 2.73 & 2.6 \\
\hline Long period required for BPR design and implementation & 2.47 & 2.6 \\
\hline Lack of benchmarking & 3 & 2.45 \\
\hline Inadequate IT infrastructure & 2.6 & 2.43 \\
\hline Lack of top-management support & 2.93 & 2.37 \\
\hline Lack of BPR tools & 2.6 & 2.3 \\
\hline Incomplete BPR methodologies & 2.5 & 2.14 \\
\hline
\end{tabular}

Table 3. Barriers to the successful implementation of BPR projects in Croatian companies (1-5 scale). 
tives. Verbal communication with IS executives is clearly important since the respondents could not self-select the questions and topics.

The questionnaire was sent to 400 IS executives in Croatian companies selected from the Register of the '400 Largest' Croatian companies, which most likely represent the structure of Croatian economy. In this Register, companies focusing on various business activities were ranked according to 2001 annual revenues. Although they represent fewer than $1 \%$ of total number of registered companies in Croatia, these sampled companies held $73 \%$ of the equity capital in the Croatian economy in 2001, accounted for $65 \%$ of the total Croatian export balance and employed $37 \%$ of the total number of workers in Croatia.

The survey received 116 responses, which represents a strong response rate of $27 \%$. More than one-half of the responding companies are included in only two industry branches, (wholesale and retail trade $-36.2 \%$ and manufacturing - 18\%) and can be considered representative for the overall structure of the Croatian economy, with trade as the prevailing economic activity as opposed to manufacturing. Furthermore, the surveyed companies were evenly distributed through Croatia, though the majority are located in Zagreb, the capital and economic centre of Croatia, and its surrounding areas, such that a regional bias in the results cannot be excluded. Regional issues were of less importance concerning the 2001 annual revenues. Regarding the sample, proposed methodology and professionalism in planning and conducting the research, the results may be considered representative.

\section{Research Results: Analysis and Conclusion}

$58.6 \%$ of all respondents (68 out of 116 surveyed IT managers) are familiar with the term BPR, while $73.5 \%$ consider that BPR projects can influence company competitiveness and solve key business processes. According to the surveyed respondents, key business processes are: integration and control of all business processes (average score 4.44 on a 1-5 scale), IT as a strategic tool in decision making process (4.34), IT efficiency (4.3) and level of efficiency related to competitive companies (4.18).
Furthermore, $94.4 \%$ of surveyed IT managers stated that IT plays a key role in BPR project success (as compared to only $80 \%$ in the 2000 survey). This finding implies the strategic role of IT in business, which is far from being true. Recent research (Spremic et al., 2002) suggested that in Croatian companies, IT is still considered no more than a tool for the automation of current business processes, completely neglecting the challenging role of IT as a competitive resource. This research identified that the source of the problem is lack of knowledge and interest in IT among top management structures and suggested that the IT manager position should be promoted to the strategic decision making level and IT departments should be in a position to perform cross-functional activities in order to gain strategic advantages from IT.

As illustrated in Table 2, in 2002, only 4 BPR projects were completed in the surveyed companies (or 6.4\%), 14 are still in progress, while 7 $(11.3 \%)$ are to be conducted in 6 months' time, $20(32.3 \%)$ are planned for the next 2 years and 6 projects $(9.7 \%)$ will be conducted in 5 years or so. These findings indicate positive planning trends: more than half of the surveyed companies (53\% cumulative) have planned BPR projects in the near future (6 months), mid-term future ( 2 years) or long-term future ( 5 years), while the number of companies not considering any BPR projects is dropping (from $29 \%$ in 2000 to $17.7 \%$ in the 2002 survey).

Indifference and lack of support from top management, in addition to the high cost of BPR project implementation, are considered to be the major barriers to the initiation of BPR projects or business process innovation projects. Current operating results in the majority of Croatian companies are far from ideal in making their management highly successful and excusing them for having a reactive and passive attitude towards business process innovation efforts.

Only 10 completed BPR projects from the first (2000 survey) and final (2002 survey) parts of the research are insufficient for an in-depth investigation or analysis of their characteristics. Nevertheless, research findings indicate that Croatian companies are making more efforts regarding BPR than in the 2000 survey. 


\section{Case Study of a Pharmaceutical Company Pliva}

Since its 1996 listing on the London and Zagreb Stock Exchanges, PLIVA has made notable advancements in internationalizing its business and implementing global and innovative strategies. PLIVA is a rather unique company with investments in both research and development. With over 400 patents in its possession, PLIVA has proven the high calibre of its R\&D capabilities, most notably through the discovery of its blockbuster - azithromycin. This macrolide antibiotic, globally known as Zithromax (under license to Pfizer) or Sumamed (PLIVA's brand), is the top selling antibiotic in its class.

PLIVA is the largest pharmaceutical company by turnover in Central and Eastern Europe and continues to expand its operations with recent acquisitions of pharmaceutical and R\&D companies in the Czech Republic, France, Germany, the United Kingdom and the USA. With increasing efforts concentrating on the global pharmaceuticals market, PLIVA has divested its cosmetics, food and agrochemicals production units as stand alone companies.

PLIVA consists of 44 legal entities, has 5 major business divisions (research, fine chemicals, pharmaceutical, OTC, DDI) and 9 strategic/corporate divisions (development, regulatory affairs, finance, human resources, IT, quality assurance, legal affairs, corporate communications and engineering). PLIVA employs almost 7500 people in 33 countries (including 120 IT professionals, not including out-ofhouse consultants), has 5 main production locations (Croatia, Czech Republic, Poland, Germany and the USA) and 43 subsidiaries in 23 countries.

\subsection{SAP Software Solutions in PLIVA}

The development of a modern ERP system to support these business operations, began in $1995 / 6$ with projects intended to advance individual modules or sectors of IS. Up until that time, PLIVA had a classical transaction information system with centralized, hand-entered data. Pressured by a lack of time for independent development of a new integrated system, the management decided on the purchase of a compete system, keeping the SAP package in mind (alternatives were IBM, BAAN and Oracle). Today, according to the assessments of independent research, SAP Croatia holds $25 \%$ of the domestic business software market. In Croatia, SAP has 35 large clients including PLIVA, Podravka, Ericsson and Croatian Telecom, and most interestingly, the State Treasury (Vecernji List, 2002).

The implementation of the SAP solution took place in individual phases, with two modules in the area of cost center accounting and profit center accounting implemented in 1997. This enabled the better control of financial resources, forecasts and a new type of analysis.

During the implementation of the IS, the consulting company PriceWaterhouseCoopers conducted a reengineering project, or the re-organization of business operations aimed at determining the key sectors of future operations: the 'core business'. Though these were two fully independent projects, they were harmonized at the level of the steering committee. SAP modules were implemented through 4 phases:

\section{1. phase: 1996-1997 (SAP 3.0)}

- FI - Financials

- $\mathrm{CO}$ - Controlling

- $\mathrm{BC}$ - Basis components

- UPGRADE 3.0-3.1 H

\section{2. phase: 1998-2000}

- $\mathrm{MM}$ - Materials Management

- PP - Production Planning

- QM - Quality Management

- $\mathrm{SD}$ - Sales \& Distribution

- WM - Warehouse Management

- HR - Human Resources

- UPGRADE SAP 3.1H-4.0B-2000 (JAN)

- UPGRADE 4.0B-4.6 C 2000 (JULY) 


\section{3. phase: 2001}

- PP-PI - Production Planning-Process industries-extension of PP module

- QM module - advanced functionality of Quality Control

- PM - Plant Maintenance

\section{4. phase: 2002}

\section{- Internationall Roll-out}

A thorough review of the information system according to SAP specifications and standards was also conducted, and the implementation of the following modules is planned in 2003:

- SCM - Supply Chain Management,

- BIW - Business Information Warehouse,

- Project Systems, and

- Treasury

The transfer of operations to the new system (in the second phase of implementation) lasted 12 days, as the problem of shifting from the old coded system (taking over 'old' data) needed to be resolved, and the process of preparations and system training lasted 4 months in 2 shifts, which included 700 employees (average training period of 7 days per employee). During the transfer to the new system, operations were halted for 10 days, while inventory and a detailed financial harmonization were conducted.

In addition to resistance to change (particularly emphasized with warehouse employees), the most significant problems in the system implementation were the weak experience and quality of consultants who bid in the public tender, the lack of time and the specificity of the pharmaceutical industry (strictly regulated quality of raw materials, the obligation of non-stop production).

During the implementation of the new information system and in running information systems in general, project organization with the usual participants stands out: the project sponsor, steering committee, project teams, team leader (most often a person outside the information specialization), functional teams and team members. An interesting organizational solution are the validation teams, which are separate from the project teams, and whose tasks are control of the teams' work, measuring harmonization with business plans and goals and coordinating the cross-functionality of teams. The validation team is led by a person from Quality Assurance, responsible for validating the information system, while the team members report to the project manager for coordination and delivery, who is appointed by the director of QA (Quality Assurance). The members of the validation team are also team leaders for the remaining teams in the project. The Information Department in PLIVA has a strategic position in the company, is directly responsible to the company management and is developing as a profit center, meaning that daughter companies are billed for the use of the information system and the transfer of the existing system is underway in the daughter companies (roll-out in Czech Republic in 2003 and in Germany in 2004). Considering that PLIVA has over 1500 SAP licenses, a help desk, ABAB programmers, highly educated employees (18 employees are SAP consultants) and an organizational management for user support, all the conditions have been set for PLIVA to become a SAP Customer Competence Center (certification in progress), which would then reduce the costs of license maintenance to $20 \%$.

In 2001, the PLIVA Information Department achieved USD 1 million revenue. Information strategy stems from the strategic business plans, in which $2 \%$ of the revenue is earmarked for information, and the IT Committee provides global initiatives and a strategic development direction. In addition to the plans to implement new ERP modules (SCM, CRM), PLIVA also plans to create in the near future a unique methodology for project management.

\subsection{Discussion and Evaluation of the Research Results}

Information is a connective tissue in business, as it connects various sectors of the business system, various business organizations, various business functions and processes, thus permitting efficient coordination and control of overall business operations. Information, as a valuable intangible business resource, is neither sim- 
ple nor inexpensive to create. Its creation requires the aggregation of transaction data and the engagement of specific techniques, knowledge and business resources.

Modern ERP systems permit the aggregation of virtually all forms of transaction data involved in business operations and those of business partners, thus creating high quality information support and pre-conditions for a completely different way of doing business. The implementation of a new ERP system will not bring the expected benefits if it is not accompanied by a change in human behaviour and in organizational regulations. There is no point in implementing a new ERP system if a business will then simply continue with its old, inefficient ways. For example, the implementation of a buyer line of credit and prompt data entry will create the pre-conditions for sales staff to receive information on the credit capabilities of clients, however, the true effects are achieved only when the sales staff receive authorization to resolve problems and make the appropriate decisions (for example, to decide on the client's credit capabilities). Therefore, the implementation of ERP systems must be accompanied by a thorough business reengineering project, and changes in the usual way of doing business and adaptations of organization solutions to the intensive flow of information among various business functions and processes.

The conclusions received on the basis of the research conducted in PLIVA can be compared to the research results described in Section 4.2.

H1: the results of research on BRP projects conducted in Croatian companies show that managements of Croatian companies primarily have a reactive approach to process of business innovations - this hypothesis did not prove to be true in the case of the pharmaceutical company PLIVA, where a BRP project was conducted side-by-side with the implementation of the ERP system. The example of PLIVA shows that successful implementation of the ERP system must be accompanied by an appropriate BRP project. From this example, it is possible to conclude that the final results are positive, even when these are completely separate and independent projects, which are harmonized at the level of the project steering committee. In this respect, the PLIVA case is interesting as this is an international company which has dedicated much attention to employee training (and which has had standing cooperation with the Management Center Europe for many years) with the goal of achieving maximal flexibility and readiness for constant organizational changes (organizational change and change management training). This long standing cooperation has resulted in an internal training program which PLIVA employees carry out according to the methodologies of the Management Center Europe.

If we compare the results of the research conducted in PLIVA with the hypotheses of research of the application of ERP systems in Croatia (Fertalj et al., 2002), as described in Section 3.2, the following conclusions, similarities and differences are obtained:

H2: the best supported components are Finance and Sales - does not agree with the research of ERP system application in Croatia, for even though product planning and management were implemented in the beginning, there were no significant problems and very good results ensued. This indicates that good project management and coordination with the BRP project gives a good final outcome;

H3: time of implementation is 3-4 years agrees with the research on ERP system application in Croatia (in continued research), as the project of implementing 4 phases of the SAP system in PLIVA also lasted that long. The length of implementation time of such a system can be critical, because valuable business resources are engaged over the long term, frequently with an uncertain ending, as it was in a case of SAP system implementation in Nestlé, USA (CIO, 2002). On the other hand, the phase-by-phase approach used in the case of PLIVA could be assumed as the critical factor of successful implementation.

H4: problems with consultants - agrees with the research, as according to PLIVA experts, it was very difficult to find good quality consultants, particularly financially available consultants with experience in implementing the SAP system in pharmaceutical industries. As such, PLIVA was forced to repeat its public tender for consulting services several times as they were not satisfied with the services offered.

H5: high costs of consulting services - agrees with the research, however, the high initial con- 
sulting costs can be reduced if the employees themselves become consultants, as in the case of PLIVA (18 employees are SAP consultants). PLIVA has achieved all the criteria necessary to become a SAP Customer Competence Center, which would thus reduce license fees from $22 \%$ to $18 \%$. It is well known that the one-day fee for a SAP consultant is about EUR 1000, and that this price includes programming and the consultant's exceptional knowledge of business processes. According to the director of SAP Croatia, company managers often increase the costs themselves by postponing the decision to implement the consultant's recommendations, and by later seeking to change decisions which have already been made (Vecernji list, 2002).

H6: organizational changes are required - certainly in agreement with the research; though the project of implementing the ERP system and the BRP project were independent, they were coordinated at the level of the project steering committee, which permitted proper execution of wide-reaching organization changes and contributed to the overall success of the ERP system implementation.

H7: advantages provided by the ERP system include standardization of business processes and consolidation of financial data - in agreement with the research of ERP system implementation in Croatia, however, it must be noted that the implementation of this system in PLIVA resulted in many additional tangible and intangible benefits.

The basic tangible benefits stemming from the implementation of the ERP system are:

- reduction of overall inventory by at least $30 \%$, thus increasing the coefficient of turnover,

- reduction of product delivery time to the buyer from 4 days to 24 hours,

- reduction of the number of employees by 20$30 \%$ in functions where the new system was implemented (redistribution of work meant savings),

- reduction in the number of complaints due to mistakes in delivery (complaints reduced to a minimum)

- reduction of time of payment by $30 \%$ with the implementation of the buyer's credit limit.
It must be stressed that certain benefits can be directly evaluated and predicted, while others are more difficult to measure or evaluate in advance (intangible benefits). Some intangible benefits might be the improved image of a company as a whole, an increased market share, better relationships with business partners, increased customer satisfaction, better data quality for business decision making and better relationships with suppliers. The basic intangible benefits from the implementation of the new ERP system in PLIVA are:

- improved transparency of the "workflow systems" and their coordination,

- secured forecasts of money flows and planning of available financial resources for a more rapid execution of all business processes,

- centralized supply (6-7 employees for the entire company) as a result of the BRP project,

- better (monthly) production planning (based on market needs and standing inventory),

- better flexibility of the system with regard to business decisions,

- automated warehouse (implementation of real warehouse with optimized selection and delivery of products),

- well-informed decision making, new quality in planning and forecasting.

\section{Conclusions}

The ERP market, or as the IDC appropriately calls it, the Enterprise Application Suite Market $(E A S)$, has become one of the fastest growing segments of the IT market in Croatia over the last few years, and will continue to grow in the coming years. According to IDC assessments, the value of the market for licensing and project services, implementation and maintenance of ERP software in Croatia totaled about $\$ 27$ million in 2001. It is expected that some 2000 businesses in Croatia will plan, purchase, supplement and modernize their business information systems in the near future.

This study has supported the set hypotheses on the need for parallel projects for organizational change with the implementation of new programming solutions, as well as the possibility 
of their successful implementation, as shown in this case. The results presented have outlined the problems of Croatian companies in the implementation of reengineering projects, including: a lack of preparation for large organizational changes, resistance to change, inadequate information education of employees, lack of strategic planning and vision and a reactive role of the management. The problems associated with ERP solution implementation were also analyzed, such as: large initial investments, need to adapt to software solutions and the long implementation period. This case study shows that with the right management decisions and actions, through simultaneous and coordinated projects of business process reengineering and the development of an integral information system, poor effects of the listed problems can be minimalized or eliminated, which is clear from the tangible and intangible benefits outlined in this case study.

The authors will continue this research, comparing similar projects in other companies in Croatia and abroad, in order to secure credible results and comparisons on a large sample size.

\section{Acknowledgment}

The authors are grateful to the IT managers of surveyed Croatian companies who took their time to respond to the questionnaire and to those who participated in the conducted survey. We also gratefully acknowledge the contributions of Marijo Volarevic, Head of IT End-User Support in PLIVA and Mirko Slovljak, Head of Corporate IT Business Support in PLIVA, who participated in interviews and provided in-depth knowledge for the PLIVA case study research.

\section{References}

[1] P. K. AHMED, Magic bullets of process change? TQM and BPR, Business Process Management Journal, Vol. 5, No. 4 (1999), pp. 294-296.

[2] M. AL-MASHARI, M. ZAIRI, BPR implementation process: an analysis of key success and failure factors, Business Process Management Journal, Vol. 5, No. 1 (1999), pp. 87-112.
[3] R. Alt, E. Fleisch, C. Reichmayr, Developing eCommerce within Business Networks - The Case of ETA SA, presented at the Proceedings of Thirteenth International Bled Electronic Conference, (2000) Bled, Slovenia.

[4] AMR, The Report on Enterprise Management, in AMR Research, (2001) Inc:42.

[5] S. Arora, S. KUMAR, Reengineering: A Focus on Enterprise Integration, Interfaces, Vol. 30, No. 5, September-October (2000), pp. 54-71.

[6] V. Bosilu-Vuksic, M. Spremic, A. Kovacic, Managing Change Toward e-Business Era: Slovenian and Croatian Perspectives - invited paper, presented at the Proceedings of Days of Slovenian Informatics - DSI, (2001) Portoroz, Slovenia.

[7] S. L. CHANG, Information technology in business processes, Business Process Management Journal, Vol. 6, No. 3 (2000), pp. 224-237.

[8] J. CHENN, Planning for ERP systems: analysis and future trend, Business Process Management Journal, Vol.7, No. 5 (2001), pp. 374-386.

[9] CIO, Nestle ERP Odyssey - December 2002 (2002), http: //www. cio.com/archive/051502/ nestle.html

[10] S. Collet, SAP Gets Stuck in the Spin Cycle, Computerworld, Vol. 33. No. 45 (1999), 1.

[11] T. H. DAVENPORT, Process Innovation: Reengineering Work Through Information Technology, Harvard Business School press, Boston, 1993.

[12] T. H. DavenPort, M. C. BeERs, Managing Information about Processes, Journal of Management Information Systems, Vol. 12, No. 1 (1995), pp. $57-81$.

[13] T. H. Davenport, Putting the enterprise into the enterprise system, Harvard Business Review, Vol. 76, No. 4 (1998), pp. 121-31.

[14] T. H. DaVEnPorT, J. E. ShorT, (1990) The New Industrial Engineering: Information Technology and Business Process Redesign, Sloan Management Review, Vol. 31, No. 34 (1998), pp. 11-27.

[15] C. X. Escalle, M. J. Cotteleer, R. D. Austin, Enterprise Resource Planning (ERP): Technology Note, Harvard Business School Publishing, Boston, MA, 1999.

[16] K. Fertalu, V. Mornar, D. Kovac, N. Hadina, P. PALE, B. ZITNIK, Komparativna analiza programske potpore informacijskim sustavima u Hrvatskoj, Projekt primjene IT proveden uz potporu Ministarstva znanosti i tehnologije (2002).

[17] R. D. GALLIERS, Reflections on BPR, IT and Organizational Change, in: Galliers, R. D., W. R. J. Baets, (ed.), Information Technology and Organizational Transformation, John Wiley \& Sons, New York, 1998.

[18] D. GRANT, A Wider View of Business Process Reengineering, Communications of the ACM, February 2002, Vol. 45, No. 2 (2002), pp. 85-90. 
[19] V. Grover, M. Malortha, Business process reengineering: a tutorial on the concept, evolution, Method, technology and application, Journal of $\mathrm{Op}$ erations Management, Vol. 15 (1997), pp. 192-213.

[20] M. HAMMER, J. CHAMPY, Reengineering the corporation: a manifesto for business evolution, Harper Collins Publishers, 1993.

[21] IDC, The Integrated Enterprise Resource Management Software Market in Croatia, 1999-2004, IDC East Central Europe, Prague (2000).

[22] R. KaLAKOTA, M. RoBinson, e-Business 2.0, Addison-Wesley, 2001.

[23] C. KOCH, BPR and ERP: realising a vision of process with IT, Business Process Management Journal, Vol.7, No. 3 (2001), pp. 258-265.

[24] S. KonICKI, Nike Just Didn't Do it Right, Says I2 Technologies, Informationweek, March 5 (2001), 32.

[25] Kovacic, A. GrozniK, M. Krisper, Business Renovation: From Business Process Modelling to Information System Modelling, Journal of Simulation, Vol. 2, No. 2 (2001), pp. 41-50.

[26] L. LeDERER, V. SETHI, Key Prescriptions for Strategic Information Systems Planning, Journal of MIS, Vol. 13, No 1. (1996), pp. 35-62.

[27] M. Markus, C. TANis, P. Fenema, Multisite ERP Implementation, Communication of the ACM, Vol. 43, No. 4 (2000), pp. 42-46.

[28] M. A. OulD, Business Processes: Modelling and Analysis for Reengineering and Improvement, Willey, 1995.

[29] D. PHIPPS, IT Strategies for E-Business That Work. Presented at the Proceedings of Symposium Itexpo - Gartner Group, (2000) Orlando, Florida.

[30] PRASSAD, Hybrid re-engineering strategies for process improvement, Business Process Management Journal, Vol. 5, No. 2 (1999), pp. 178-197.

[31] A. Ptak, E. Schragenheim, ERP: Tools, Techniques, and Applications for Integrating the Supply Chain, CRC Press-St Lucie Press, 1999.

[32] SAP, SAP Corporate Press Release - June 13, 2001 (2001), http://www.sap.com

[33] S. R. SiRIGINIDI, Enterprise Resource Planning in Reengineering Business, Business Process Management Journal, Vol. 6, No. 5 (2000), pp. 376-391.

[34] SOH, S. KEIN, T. J. YAP, Cultural fits and misfits; is ERP a universal solution?, Communication of ACM, Vol. 43, No. 4 (2000), pp. 47-51.

[35] M. Spremic, I. Strugar, Strategic Information System Planning in Croatia: Organizational and Managerial Challenges, International Journal of Accounting Information Systems, Vol. 3, No. 3 (2002), pp. 183-200.

[36] C. Stedman, Failed ERP Gamble Haunts Hershey, Computerworld, Vol. 33, No. 44 (1999), 1.
[37] P. A. TRUNICK, ERP: promise or pipe dream?. Transportation \& Distribution Journal, Vol. 40, No. 1 (1999), pp. 23-6.

[38] K. Tumay, Business Process Simulation. Presented at the Proceedings of the 1995 Winter Simulation Conference, (1995) Washington DC.

[39] VeCERnJI LIST, Poslovni svijet - Softver (2002), http: //www. vecernji-list.hr/POSLOVNI/ 2002/01/09/Pages/uhrvats.html

Received: September, 2003 Accepted: September, 2004

Contact address: Vesna Bosilj Vuksic Graduate School of Economics \& Business University of Zagreb Trg J. F. Kennedyja 6 10000 Zagreb Croatia e-mail: vesna.bosilj@efzg.hr

Mario Spremic Graduate School of Economics \& Business University of Zagreb Trg J. F. Kennedyja 6 10000 Zagreb Croatia e-mail: mario.spremic@efzg.hr

VeSnA BosiLj VuKsiC received a Dipl.Econ., M.Sc. and Ph.D. in In formation Systems from the University of Zagreb. She is an associated professor of simulation modelling and business computing at the Graduate School of Economics \& Business, University of Zagreb. Her current research interests focus on graphical methods in simulation modelling, business process reengineering, information systems development and knowledge management. She is a former president of the Croatian Society for Simulation Modelling (CROSSIM).

MARIO SPREMIC received a B.Sc. in Mathematical Sciences, M.Sc. in IT Management and Ph.D. in Information Systems from the University of Zagreb. He is assistant professor of IT management and business computing at the Graduate School of Economics \& Business, University of Zagreb. His current research interests focus on information system strategy, IT management, information system audit and e-business. He has also worked as a programmer, software engineer and project manager. 